\title{
The perception of the problems of teaching experimental sciences
}

\section{La percepción de los problemas de la enseñanza de las ciencias experimentales}

\author{
MONROY-CARREÑO, Mireya $\dagger^{*}$, MONROY-CARREÑO, Patricia and MONROY-CARREÑO, \\ Roberto
}

Escuela Nacional Colegio de Ciencias y Humanidades plantel Vallejo-UNAM

ID $1^{\text {st }}$ Author: Mireya, Monroy-Carreño / ORC ID: 0000-0002-3611-8532, CVU CONACYT ID: 743139

ID $1^{\text {st }}$ Co-author: Patricia, Monroy-Carreño / ORC ID: 0000-0002-2735-7208, CVU CONACYT ID: 424764

ID $2^{\text {nd }}$ Co-author: Roberto, Monroy-Carreño / ORC ID: 0000-0002-2556-1723, CVU CONACYT ID: 856509

DOI: $10.35429 / J H S .2021 .13 .5 .1 .12$

Received January 10, 2021, Accepted, March 30, 2021

\begin{abstract}
At present, it is required that a greater number of individuals have a scientific education to meet the requirements of a changing and globalized world, however, different investigations indicate that a very low percentage of students of High School Level wish to study a career related to the area of science, therefore, the main objective of this research is to diagnose the main difficulties in teaching and learning experimental science subjects. This study was of an exploratory cross-sectional nature, therefore two surveys were applied, one designed for students and the other for teachers from four preuniversity education institutions, thus obtaining a sample of 233 students and 79 teachers, finding as a result that one of the main problems was focuses on youth motivation, which is linked to selfdetermination and self-efficacy; which perhaps tend to be caused mainly by the dynamics used by teachers, in conclusion it is necessary to change certain aspects of the teaching process used in class, in order to influence the motivation and interest of students in the study of this área.
\end{abstract}

Learning, Teaching, Motivation

\begin{abstract}
Resumen
En la actualidad, se requiere que un mayor número de individuos tenga una educación científica para atender los requerimientos de un mundo cambiante y globalizado, sin embargo, distintas investigaciones aluden que un porcentaje muy bajo de los alumnos de Nivel Medio Superior, desean estudiar una carrera relacionada con el área de ciencias, por ende, el objetivo principal de esta investigación es diagnosticar las principales dificultades de la enseñanza y el aprendizaje de las asignaturas de ciencias experimentales. Este estudio fue de carácter transversal exploratorio, por ello se aplicó dos encuestas una diseñada para alumnos y otra para profesores de cuatro instituciones de educación preuniversitaria, obteniendo así una muestra de 233 alumnos y 79 docentes, hallando como resultado que uno de los principales problemas se enfoca en la motivación de los jóvenes, que se vincula a la autodeterminación y la autoeficiencia; las cuales quizás suelen ser ocasionadas principalmente por la dinámica empleada por los docentes. En conclusión, es necesario cambiar ciertos aspectos del proceso de enseñanza utilizados en clase, con el fin de incidir en la motivación e interés de los estudiantes en el estudio de está área.
\end{abstract}

Aprendizaje, Enseñanza, Motivación

Citation: MONROY-CARREÑO, Mireya, MONROY-CARREÑO, Patricia and MONROY-CARREÑO, Roberto. The perception of the problems of teaching experimental sciences. Journal High School. 2021. 5-13: 1-12

\footnotetext{
* Author Correspondence (e-mail: m.monroy449@gmail.com).

$\dagger$ Researcher contributing as first author
} 


\section{Introduction}

Nowadays it is required that the new generations join the research tasks, in order to reproduce the institutional structures of higher education, science and technology, for this it is necessary that there be the availability of scientists and engineers to attend techno-scientific matters and be at the forefront of the information and knowledge society.

From the previous perspective, the study of experimental science subjects allows students to acquire advanced knowledge about complex processes and procedures, which explain numerous real-world situations (Herrada \& Baños, 2017), therefore, the role of teachers In this field of study, it must be decisive and significant in the classroom, with the sole purpose of generating in them an understandability of natural phenomena and their relationship with the dynamics of the development of young people in society (Agudelo et al. ., 2021, p.160).

However, there is great concern about school failure; in particular for the subjects that make up the Area of Experimental Sciences (ACE), without ignoring that different investigations have shown that scientific vocations are particularly acute for the areas of natural and exact sciences; also for some branches of engineering, reflecting a lack of interest by young people to study a career related to science (Polino, 2012), either due to the lack of knowledge about jobs related to this field of study when leaving the bachelor's degree or by the time it takes to pursue a career in this field (Torres, 2020, p.78).

It is necessary to specify that they are working with students of the XXI century, with teachers of the XX century and methodologies of the XIX century, therefore, teachers must take on new roles and create new strategies to provide students with tools to learn to learn (Likert, 2010), so the essential problem in science teaching is to abandon an outdated conception of the mid-twentieth century for a conception that responds to the characteristics of the current context (Bosch, 2014, p.36), that is, renounce passive-accepting environments, where traditional methodologies prevail, which leave little space for the student to investigate and delve into topics of interest to them (Molina \& González, 2021).
It should be mentioned that some of the reasons for the disinterest of students towards the study of science is the little or no relationship that exists between the way it is taught and the connection with the world that surrounds them, its lack of practical applications and the little relationship between science, technology, society and the educational process (Torres, 2010).

On the other hand, the reality in the educational field is that most of the ACE teachers have a degree in basic sciences related to biology, physics or chemistry and the absence of qualified teachers in the area of education is very notable (Barberá, 2002 ), therefore, it is essential to change this reality, given that "a society without scientific knowledge is condemned to abandonment, poverty, wars and even its own extinction" (Ortiz \& Álava, 2021, p.25).

Based on the above, the following questions arise: What are the main factors that affect the teaching-learning process at ACE? Why are young people not interested in studying careers related to ACE? Which leads to This study sets out the objective of diagnosing the main difficulties in teaching and learning experimental science subjects at the Upper Secondary Level (NMS).

\section{Difficulties in teaching experimental science}

The teaching of science presents a series of difficulties in the teaching-learning process, perhaps one of the main problems is that students do not link the learning addressed in school to other contexts, therefore, they do not provide solutions to certain phenomena where they put their knowledge into play (Lorca \& Retana, 2021, p.30).

This may be due to the fact that the students consider the ACE subjects difficult, boring and irrelevant, as they are not related to their interests and experiences; if it is added that these subjects teach scientific content that especially promote negative emotions (Dávila et al, 2015); Then it follows that it is necessary to implement strategies that improve the performance achieved so far, therefore, it is important to identify which are the main problems faced by the ACE. 
In order to propose holistic solutions that contribute to improving the performance of young people, for Therefore, Table 1 presents some of the difficulties in teaching science, according to a review of the literature.

\begin{tabular}{|c|c|}
\hline Author (year) & $\begin{array}{c}\text { Difficulties in the educational process } \\
\text { at ACE. }\end{array}$ \\
\hline $\begin{array}{l}\text { Araújo } \quad \& \\
\text { Ballesta }(2019)\end{array}$ & $\begin{array}{l}\text { It is far from the everyday, emphasizing } \\
\text { abstract, unattractive content or without } \\
\text { empirical correlates, focusing on a } \\
\text { propaedeutic purpose and the presentation } \\
\text { of an academic, classical, 19th century } \\
\text { science (p.12). }\end{array}$ \\
\hline Bosch (2014) & $\begin{array}{l}\text { It is developed in a theoretical context } \\
\text { describing content and whose focus has as } \\
\text { a consequence, leaving inaccurate } \\
\text { conceptions and beliefs in students that } \\
\text { science is made up of isolated facts (p.57). }\end{array}$ \\
\hline $\begin{array}{l}\text { Chamizo \& } \\
\text { Pérez (2017). }\end{array}$ & $\begin{array}{l}\text { Students do not understand what the } \\
\text { objective of doing an activity is and many } \\
\text { assume that they do it properly, when they } \\
\text { correctly follow the instructions received } \\
\text { and finish in the established time (p. 31). }\end{array}$ \\
\hline $\begin{array}{l}\text { Dávila, et al. } \\
(2015)\end{array}$ & $\begin{array}{l}\text { Teach scientific content that mainly } \\
\text { promote negative emotions. }\end{array}$ \\
\hline $\begin{array}{l}\text { Furman, et al. } \\
(2018)\end{array}$ & $\begin{array}{l}\text { Mechanical repetition and memorization } \\
\text { of facts, definitions and algorithms (p.83). }\end{array}$ \\
\hline $\begin{array}{l}\text { Garzón \& Pérez } \\
\text { (2015) }\end{array}$ & $\begin{array}{l}\text { Language is not considered as a means of } \\
\text { communication of knowledge, which is } \\
\text { far from the social and cultural context of } \\
\text { the students. }\end{array}$ \\
\hline $\begin{array}{l}\text { González } \\
(2015)\end{array}$ & $\begin{array}{l}\text { Lack of knowledge to teach and lack of } \\
\text { knowledge of how to teach it (p.18). }\end{array}$ \\
\hline López (2015) & $\begin{array}{l}\text { Challenges of the environment in } \\
\text { contextual aspects in relation to the } \\
\text { characteristics of the students, the } \\
\text { educational environment, the aims, } \\
\text { purposes and values of teaching (p.76). }\end{array}$ \\
\hline $\begin{array}{l}\text { López, Ramírez } \\
\& \quad \text { Espinoza } \\
(2018)\end{array}$ & $\begin{array}{l}\text { The little use of experimental practices, } \\
\text { and in most cases they work from } \\
\text { predetermined guidelines that do not } \\
\text { achieve a correct mediation between } \\
\text { theory and practice (p.254) }\end{array}$ \\
\hline Macedo (2016) & $\begin{array}{l}\text { A teaching based on closed knowledge, } \\
\text { finished without relation between them } \\
\text { and their reality, is only in the educational } \\
\text { field. }\end{array}$ \\
\hline $\begin{array}{l}\text { Martínez \& } \\
\text { Riveros (2019) }\end{array}$ & $\begin{array}{l}\text { Isolated and } \\
\text { experiments. }\end{array}$ \\
\hline $\begin{array}{l}\text { Mendoza, Leal } \\
\& \text { Hernández, } \\
(2014)\end{array}$ & $\begin{array}{l}\text { The difficulty teachers have when finding } \\
\text { and designing strategies (p.123). }\end{array}$ \\
\hline Neira (2021) & $\begin{array}{l}\text { Teachers do not captivate their students by } \\
\text { the methodology used. }\end{array}$ \\
\hline $\begin{array}{l}\text { Ortiz \& Álava } \\
(2021)\end{array}$ & $\begin{array}{l}\text { Low importance to the rigor with which } \\
\text { scientific concepts are taught and deficient } \\
\text { epistemological training on the nature of } \\
\text { science in teachers (p.28). }\end{array}$ \\
\hline SEP (2017) & $\begin{array}{l}\text { The lack of interest, and even rejection } \\
\text { towards the study of science, associated } \\
\text { with school failure. }\end{array}$ \\
\hline
\end{tabular}

Table 1 Difficulties in teaching ACE

Source: own elaboration based on documentary research
In summary, school performance is a problem that has been studied from different points of view, and attitudes have become a fundamental issue in didactic research, since together with the conceptual and procedural components they help to better understand the educational process and thereby intervene in it; And even in countries such as the United States, England and Spain, various empirical studies have been carried out regarding the attitudes of teachers and students towards science, however, in Mexico this type of research is very limited and if it focuses on pre-university education , which for many young people constitutes the period in which the specialty is established to continue their professional studies, and for many others it will be the conclusion of their formal education (Pelcastre, Gómez \& Zavala, 2015).

\section{Methodology}

This is a field work where two evaluation instruments were implemented, with the purpose of identifying the perceptions and attitudes of students and teachers about the problems that exist in the educational process in ACE. Furthermore, this is an exploratory crosssectional study, since perceptions are personal characteristics where the researcher does not have direct control (Pelcastre, Gómez \& Zavala, 2015).

\section{Participants}

The sample consisted of pre-university education students of whom a voluntary and convenience sampling was applied to 233 students, of which 45 were studying at an Official Preparatory School (EPO), 35 were studying at a Center for Scientific and Technological Studies (CECyT ), 30 students belonged to a National Preparatory School (ENP) and 123 young people to the College of Sciences and Humanities (CCH), where $40.78 \%$ were women and $59.22 \%$ were men between the ages of $15-19$ years, $24.03 \%$ They were in the first year, $42.06 \%$ were in the second year and $33.91 \%$ were in the last year of the NMS.

Likewise, 79 teachers participated (15 teachers from EPO, 9 from CECyT, 12 from ENP and 43 from $\mathrm{CCH}$ ), of which $37.97 \%$ taught biology, 31.64\% Chemistry and 30.39\% Physics. In the same way, $24.05 \%$ have less than six years of teaching experience, $29.11 \%$ have between 6 to 10 years, $22.78 \%$ between 16 to 20 years and $24.06 \%$ more than 20 years.

MONROY-CARREÑO, Mireya, MONROY-CARREÑO, Patricia and MONROY-CARREÑO, Roberto. The perception of the problems of teaching experimental sciences. Journal High School. 2021 


\section{Evaluation instruments}

a) Students

The evaluation instrument applied to the students is made up of two sections, the first one consisting of personal and academic aspects, personal information such as sex, age, institution, general average and lastly, if they wish to enter a career at a higher level and which one is his area of interest hierarchized according to the areas of knowledge taught at the National Autonomous University of Mexico (UNAM) and the National Polytechnic Institute (IPN), the second section consisted of 45 questions, designed from the scale of Likert and based on works by Ardura \& Pérez (2018); Cuevas et al. (2016), Lupión, Franco \& Girón (2019) and Pelcastre, Gómez \& Zavala (2015) and classified in six factors (table 2):

1. Self determination: It is related to development and personality in a social context, since it promotes greater participation and socialization; at the same time, it motivates second cycle organizational learning (creativity and innovation) and adequate knowledge management (Vargas, 2013).

2. Self-efficiency: These are those thoughts of an individual related to their ability to organize and execute the actions necessary to obtain certain achievements "(Galleguillos \& Olmedo, 2017), that is, they do not refer to the changing circumstances of the academic environment, but to the opinion that he has about what he can or cannot do with them (Bandura, 1995).

3. Didactics: It is the part of pedagogy that focuses on the study of teaching strategies, tools and methods.

4. Extrinsic motivation: It is one that depends on external factors or by obtaining benefits, modifying the autonomy that the individual has (Domínguez \& Pino, 2014).

5. Intrinsic motivation: It is defined as the interest and enjoyment in an activity by itself, it involves feelings of mastery, effectiveness and autonomy that are inherent to the interest and taste in the task (Aguilar, González \& Aguilar, 2016, p.2553).
6. Motivation by study: Although this motivation is part of the intrinsic and extrinsic motivation, it is desired to evaluate the answers, depending on whether the students think differently if they are interested in the area of experimental sciences.

\begin{tabular}{|l|l|}
\hline \multicolumn{2}{|c|}{ Factor } \\
\hline Self determination & $5,7,22,30$ y 40 \\
\hline Self-efficiency & $3,4,17,18,34$ \\
\hline Didactics & $\begin{array}{l}2,8,16,21,23,25,28,29,33,35,36,37 \\
\text { y } 39\end{array}$ \\
\hline $\begin{array}{l}\text { Extrinsic } \\
\text { motivation }\end{array}$ & $14,26,32,38,42$ y 45 \\
\hline $\begin{array}{l}\text { Intrinsic } \\
\text { motivation }\end{array}$ & $1,6,9,10,12,20,24,27$ y 43 \\
\hline $\begin{array}{l}\text { Motivation by } \\
\text { study }\end{array}$ & $11,13,15,19,31,41$ y 44 \\
\hline
\end{tabular}

Table 2 Factors evaluated in the survey applied to students Source: Ardura \& Pérez (2018); Cuevas et al. (2016), Lupión, Franco and Girón (2019) and Pelcastre, Gómez \& Zavala (2015)

\section{b) Professor}

In the evaluation instrument used for teachers, aspects of their didactics (dynamics, contents, evaluation, learning, classroom climate and strategies) were evaluated, since the teacher can control and transform some of these problems from their performance; thereby influencing the motivation and perception of students. The instrument was designed from the Likert scale and based on the research of Mordeglia \& Mengascini (2014) and Cañal, García \& Cruz (2016), made up of 15 items.

For the quantitative analysis, an assessment was set for each item of the questionnaire with a Likert-type scale in which the frequency is indicated, with which they identify with the situation described in the statement. Where, the weighting is 1) Strongly disagree, 2) Disagree, 3) Undecided, 4) Agree and 5) Strongly agree. To identify the items with the greatest relevance, the mean frequency was obtained, which was calculated using the following Eq. 1:

$f=\frac{A(1)+B(2)+C(3)+D(4)+E(5)}{N}$

Where, the values $1,2,3,4$ and 5 are obtained from the Likert scale and the letters A, $\mathrm{B}, \mathrm{C}, \mathrm{D}$ and $\mathrm{E}$ are the individual index subjects and $\mathrm{N}$ is the total number of individuals per group. 


\section{Results and discussion}

Table 3 shows the general averages reported by students by institution, obtained up to the last semester or year studied at the time of applying the survey.

\begin{tabular}{|c|c|c|c|c|c|}
\hline $\begin{array}{l}\text { General } \\
\text { average }\end{array}$ & EPO & СЕСуТ & CCH & EPN & Total \\
\hline $9.0-10.0$ & 7 & 2 & 15 & 9 & 33 \\
\hline $8.0-8.9$ & 16 & 7 & 52 & 7 & 82 \\
\hline 7.0-7.9 & 10 & 12 & 41 & 8 & 71 \\
\hline $6.0-6.9$ & 12 & 14 & 15 & 6 & 47 \\
\hline $\begin{array}{ll}\text { Less than } \\
6.0\end{array}$ & 0 & 0 & 0 & 0 & 0 \\
\hline Total & 45 & 35 & 123 & 30 & 233 \\
\hline
\end{tabular}

Table 3 General averages obtained up to the last semester studied

Based on the above information, it is then summarized that $49.35 \%$ their average is greater than or equal to 8.0 which, according to Izar, Ynzunza \& López (2011), refers to the fact that students who have a good academic performance trajectory are associated with having the desire to continue preparing, in other words, they yearn to continue with their studies at the higher level, so this is reflected in Table 4 which presents the responses of the students according to their area of interest to continue with their studies at the higher level Bachelor's degree, classified with respect to the areas of study according to the UNAM and the IPN.

$\begin{array}{llll}\text { Study area EPO CECyT CCH EPN Total } & \end{array}$

\begin{tabular}{|l|r|r|r|r|r|}
\hline $\begin{array}{l}\text { Engineering and } \\
\text { Mathematical } \\
\text { Physical Sciences }\end{array}$ & 5 & 13 & 28 & 8 & 54 \\
\hline $\begin{array}{l}\text { Biological and } \\
\text { health sciences and }\end{array}$ & 8 & 8 & 39 & 9 & 64 \\
\hline $\begin{array}{l}\text { Social and } \\
\text { administrative } \\
\text { sciences }\end{array}$ & 4 & 3 & 18 & 3 & 28 \\
\hline $\begin{array}{l}\text { Arts } \\
\text { Humanities decided }\end{array}$ & 7 & 6 & 13 & 3 & 29 \\
\hline $\begin{array}{l}\text { I have not de } \\
\text { what to study }\end{array}$ & 12 & 1 & 0 & 0 & 13 \\
\hline $\begin{array}{l}\text { I am not going to } \\
\text { study a university } \\
\text { degree }\end{array}$ & 45 & 35 & 123 & 30 & 233 \\
\hline Total
\end{tabular}

Table 4 Area of interest of the surveyed students to continue their university studies

In relation to the information in Table 4, it is shown that $50.64 \%$ want to study an area of Physico-mathematical and biological sciences and health.
Likewise, it was found that only $5.57 \%$ of students do not wish to continue with their studies at the undergraduate level, however, almost all belong to the EPO, perhaps one of the reasons is that it is the only institution that is not incorporated into an institution university as is the case of the other three colleges.

Tables 5 and 6 show the mean frequencies obtained from the responses of students and teachers, according to the measurement instrument applied.

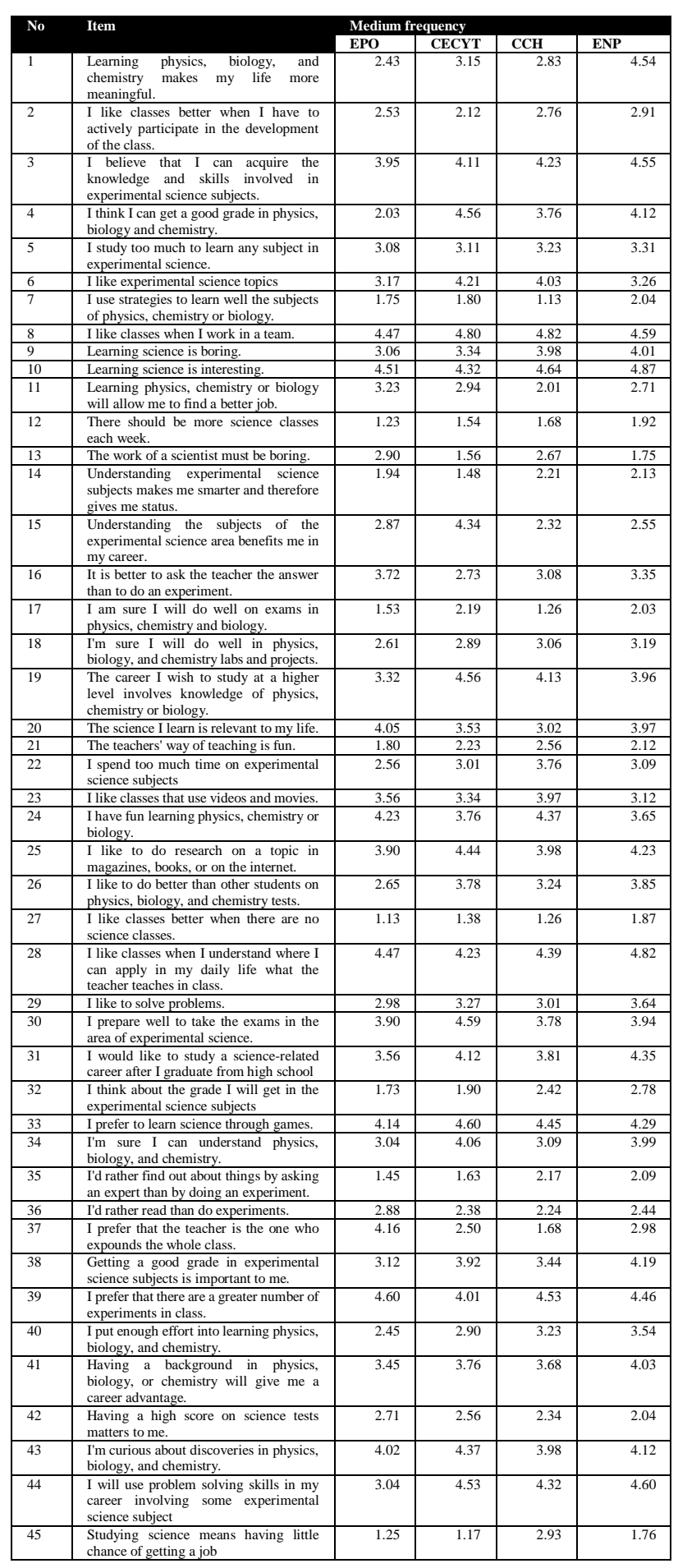

Table 5 Average frequency of student responses for the science difficulties assessment instrument obtained in different institutions to NMS 


\begin{tabular}{|c|c|c|c|c|c|}
\hline \multirow[t]{2}{*}{ No } & \multirow{2}{*}{ Item } & \multicolumn{4}{|c|}{ Medium frequency } \\
\hline & & EPO & CECyT & $\mathbf{C C H}$ & EPN \\
\hline 1. & $\begin{array}{l}\text { Textbooks are the best } \\
\text { resource for teaching } \\
\text { science. }\end{array}$ & 3.22 & 3.98 & 2.99 & 2.01 \\
\hline 2. & $\begin{array}{l}\text { Science is true } \\
\text { knowledge and does } \\
\text { not change. }\end{array}$ & 1.80 & 1.08 & 1.34 & 1.90 \\
\hline 3. & $\begin{array}{l}\text { The best way to teach } \\
\text { is from the } \\
\text { fragmentation of } \\
\text { school knowledge. }\end{array}$ & 1.78 & 3.15 & 4.17 & 3.11 \\
\hline 4. & $\begin{array}{l}\text { The study programs } \\
\text { are very long for one } \\
\text { semester. }\end{array}$ & 4.15 & 3.5 & 4.89 & 4.12 \\
\hline 5. & $\begin{array}{l}\text { It is necessary to use a } \\
\text { variety of activities to } \\
\text { build learning. }\end{array}$ & 2.56 & 3.12 & 4.08 & 4.23 \\
\hline 6. & $\begin{array}{l}\text { It is important to carry } \\
\text { out experimental } \\
\text { activities in class. }\end{array}$ & 4.57 & 4.33 & 4.81 & 4.61 \\
\hline 7. & $\begin{array}{l}\text { It is important to } \\
\text { contextualize so that } \\
\text { the student } \\
\text { understands a topic. }\end{array}$ & 4.56 & 4.10 & 4.56 & 4.63 \\
\hline 8. & $\begin{array}{l}\text { In the classes the } \\
\text { memorization of } \\
\text { concepts, formulas } \\
\text { and procedures is } \\
\text { promoted. }\end{array}$ & 1.23 & 2.56 & 3.45 & 3.01 \\
\hline 9. & $\begin{array}{l}\text { The language of } \\
\text { experimental science } \\
\text { is difficult, which } \\
\text { influences the } \\
\text { learning process. }\end{array}$ & 3.45 & 3.45 & 4.12 & 3.29 \\
\hline 10. & $\begin{array}{l}\text { Diagnostic } \\
\text { evaluations are } \\
\text { carried out at the } \\
\text { beginning of a topic } \\
\text { or a unit. }\end{array}$ & 3.12 & 4.15 & 2.45 & 4.13 \\
\hline 11. & $\begin{array}{l}\text { Hetero-evaluation, } \\
\text { co-evaluation and } \\
\text { self-evaluation in } \\
\text { classes are promoted. }\end{array}$ & 2.67 & 2.18 & 3.14 & 3.09 \\
\hline 12. & $\begin{array}{l}\text { The strategies } \\
\text { implemented are } \\
\text { related to the } \\
\text { everyday context. }\end{array}$ & 3.89 & 4.14 & 3.51 & 4.07 \\
\hline 13. & $\begin{array}{l}\text { Collaborative work in } \\
\text { class is encouraged. }\end{array}$ & 3.19 & 3.90 & 4.12 & 3.70 \\
\hline 14. & $\begin{array}{l}\text { Experimental science } \\
\text { classes are boring for } \\
\text { students. }\end{array}$ & 3.45 & 2.33 & 3.87 & 3.19 \\
\hline 15 & $\begin{array}{l}\text { Students are not } \\
\text { interested in science } \\
\text { classes and they are } \\
\text { boring. }\end{array}$ & 4.01 & 4.30 & 3.98 & 4.12 \\
\hline 16. & $\begin{array}{l}\text { Presenting examples } \\
\text { in class improves } \\
\text { understanding of the } \\
\text { topics. }\end{array}$ & 4.12 & 4.38 & 4.08 & 4.03 \\
\hline 17. & $\begin{array}{l}\text { The implementation } \\
\text { of ICT and } \\
\text { audiovisual materials } \\
\text { will improve } \\
\text { understanding of } \\
\text { science. }\end{array}$ & 4.56 & 4.34 & 4.91 & 4.78 \\
\hline 18. & $\begin{array}{l}\text { It is essential to } \\
\text { implement debates on } \\
\text { relationships between } \\
\text { knowledge }\end{array}$ & 3.90 & 3.02 & 4.09 & 3.45 \\
\hline 19. & $\begin{array}{l}\text { scientific and social } \\
\text { issues. }\end{array}$ & 3.02 & 2.18 & 3.67 & 2.90 \\
\hline
\end{tabular}

Table 6 Average frequency of the responses of science teachers regarding their dynamics
Regarding the results obtained in the selfdetermination part (graph 1), it was observed that in most of the responses they are below a mean frequency of 4.0 .

In the same sense, it is necessary to specify that in the item that refers to whether students use strategies to learn well the subjects of physics, chemistry or biology, the derived mean frequencies are equal to or less than 2.0; This means that according to the Likert scale used, they totally disagree, this may be due to the fact that self-determination is a pending task in the educational field (Mumbardó et al., 2017).

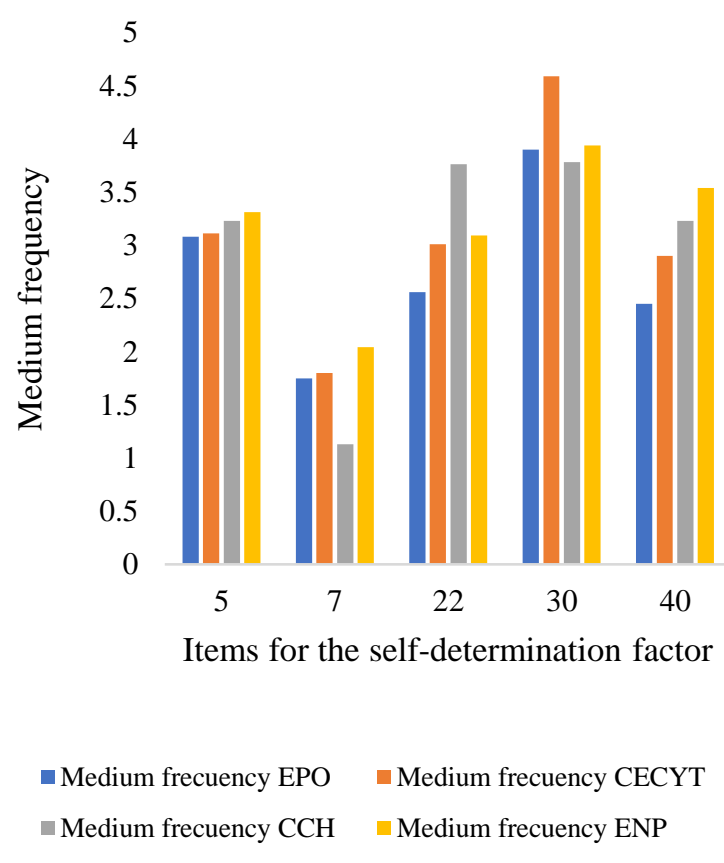

Graphic 1 Average frequency of student responses for the self-determination factor

It should be noted that working on selfdetermination within the classroom allows students the opportunity to learn strategies and fundamental experiences for their development in post-school settings (Mumbardó et al., 2017), although according to the theory of selfdetermination, motivation does not have a However, the only component that defines it is usually made up of three analysis approaches: global, contextual and situational (González, Vázquez \& Zavala, 2021).

In relation to Graphic 2, the results are presented for the self-efficiency factor, which show that the students of the EPO compared to the other institutions were those that showed a lower average frequency. 


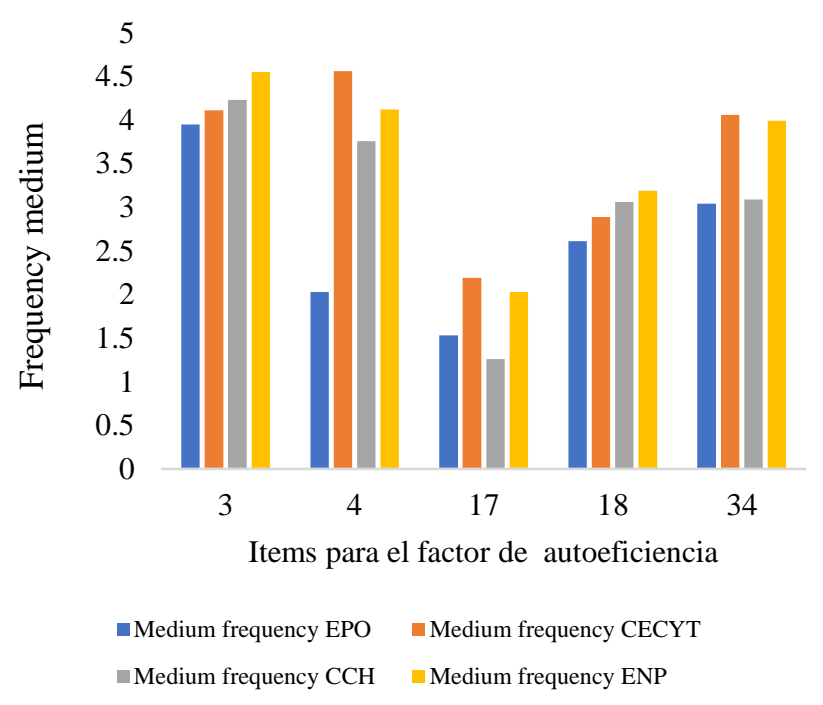

Graphic 2 Average frequency of student responses for the self-efficacy factor

In the same sense, only $11.11 \%$ of the sample for EPO wishes to study a career related to the area of Physics, Mathematics and Biological Sciences and the situation is complicated when determining that this institution the number of students who no longer wish to enter a higher level is $26.66 \%$.

It is important to mention that selfefficacy is a transcendental process at a psychological level, since beliefs regarding efficacy can determine a different academic performance in two people of the same degree of ability, which is why academic success demands regulatory processes such as self-assessment, self-monitoring and the use of metacognitive learning strategies since these processes have a positive influence, due to a high degree of belief in one's own ability (Galleguillos \& Olmedo, 2017).

It should be considered that for the factor of dynamics within the classrooms and where various investigations have focused their attention, in order to renew the teaching-learning process, it was found that the items with less frequency and where the four institutions coincide (Graphic 3) is that the teachers' way of teaching is not fun; This situation can be derived from multiple factors, however, this could be caused by the lack of professionals specializing in experimental sciences in basic education, which makes it difficult for them to design scenarios that promote meaningful learning (Molina \& González, 2021) or "not all teachers have the time or the motivation to become experts in the design of teaching strategies" (Caminal \& Puigcerver, 2021, p. 122).

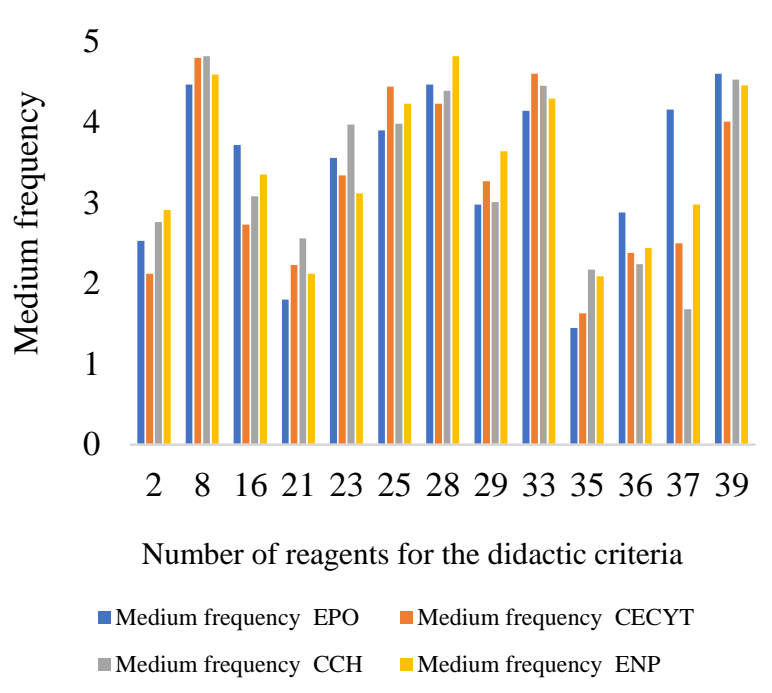

Graphic 3 Average frequency of student responses for the dynamics factor

Therefore, it is recommended to make the classes more experiential, in order to understand the natural phenomena that surround the student through a systemic approach (Rodríguez \& González, 2018).

Likewise, another question with a lower average frequency was whether students prefer to find out about things by asking an expert than by doing an experiment, this may be due to the fact that adolescents associate scientists with prestigious professionals with an important social occupation (Polino, 2012), although the experimental activities promote participation in the learners.

In the same sense, the items I prefer to read than do experiments and I prefer that the teacher be the one who presents the whole class, the students totally disagree; This could be due to the fact that pedagogical resources are vital, not only for the performance of the catalytic function that the school has on future professional choices, but also because practices in science classes are essential for the development of a critical perspective. and the construction of notions of science in action (Polino, 2012).

Now, regarding intrinsic motivation, students feel motivated when comparing themselves with the rest of their classmates, however, the mean frequencies obtained by the surveyed groups vary from one group to another, this may be due to their contexts and interests of each group. 
Therefore, in Graphic 4 shows the students' responses, highlighting the item studying science implies having few possibilities to get a job, the $\mathrm{CCH}$ students had an average frequency of 2.93 , that is, they agree with this reasoning, however, the other institutions do not agree with this perception.

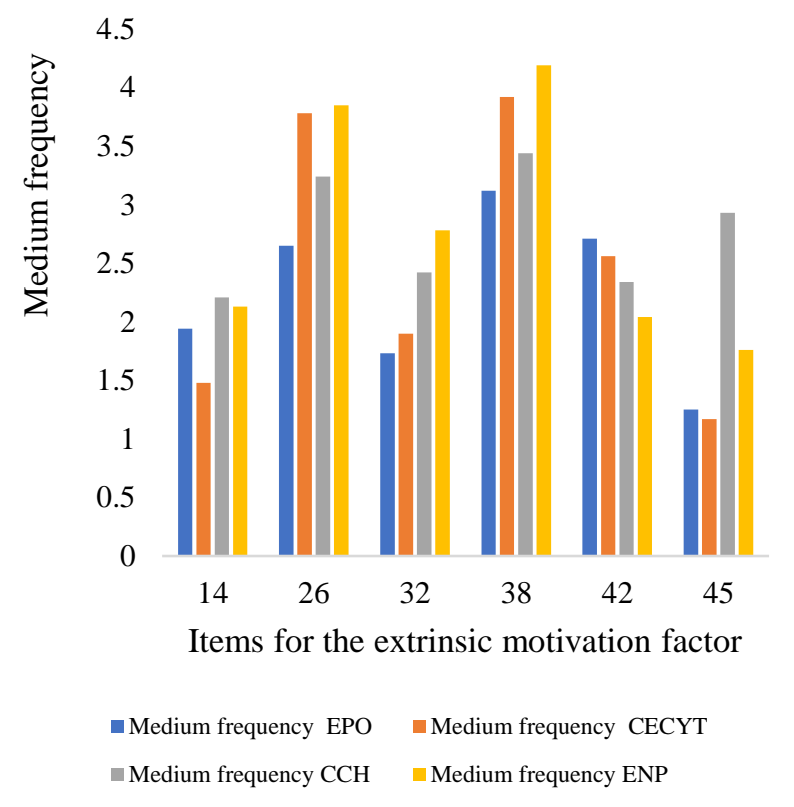

Graphic 4 Average frequency of student responses for the extrinsic motivation factor

It is important to add that the motivation of the students is fundamental, since it is one of the most conducive means to promote learning, adjusting the new learning to the real possibilities of each student (Araque, 2011), in this sense Aguilar, González \& Aguilar (2021) state that for an individual to have a high level of intrinsic motivation, it is necessary to experience the satisfaction of their needs for both competence and autonomy.

In general terms, the students with less intrinsic motivation are those who belong to the EPO (Graphic 5), this may be because they do not have a direct or indirect pass to the Higher Level as is the case of the CECyT which is to the IPN and the CCH and ENP that belong to the UNAM; As mentioned by Domínguez \& Pino (2014), motivation is a variable that depends on the personal and contextual adjustment of adolescents.

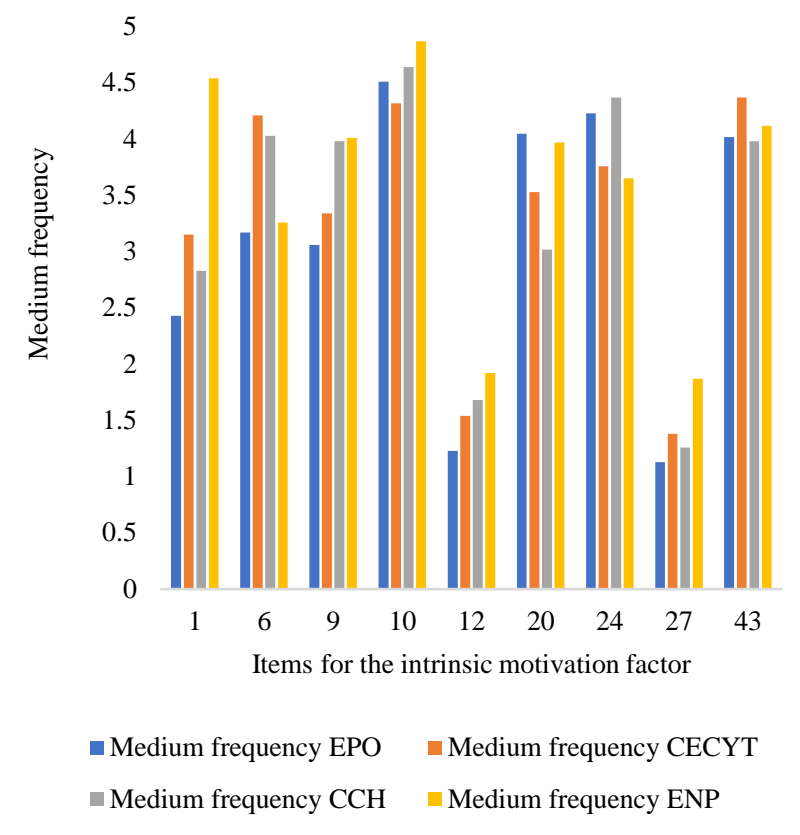

Graphic 5 Average frequency of student responses for the intrinsic motivation factor

Likewise, in the question I like to go to school more when there are no science classes, it obtained a low average frequency showing a total disagreement with this item, showing that students have a taste for science, however, perhaps one of the The main problems are due to traditional classes, in other words, there is the perception that "current science teaching does not innovate in its methodologies" (Molina \& González, 2021, p.48).

It is appropriate to add that Graphic 6 presents the motivations of the students towards the study of science, highlighting that the CECyT students obtained a higher average frequency in most of their answers, finding it useful for their personal and academic life.

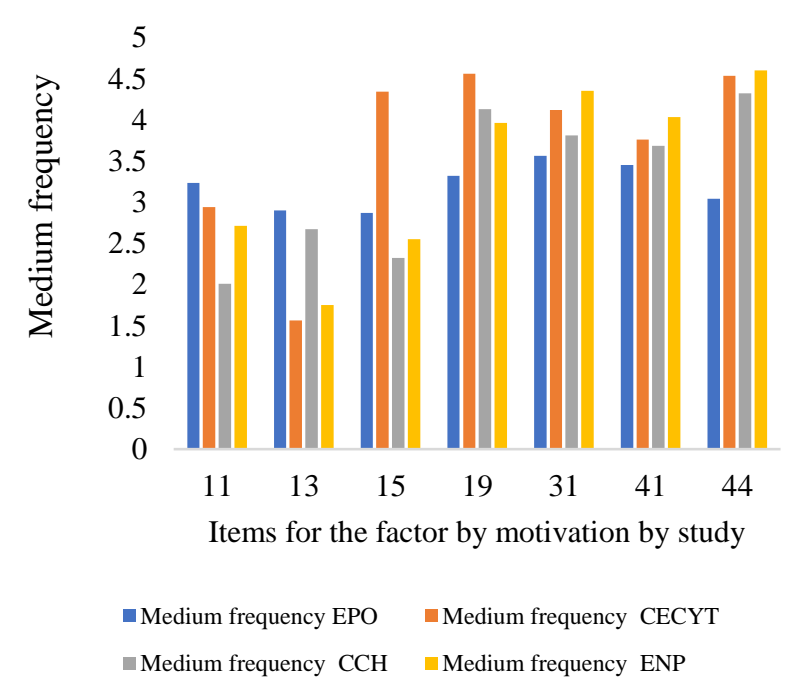

Graphic 6 Average frequency of student responses for the motivation factor per study

MONROY-CARREÑO, Mireya, MONROY-CARREÑO, Patricia and MONROY-CARREÑO, Roberto. The perception of the problems of teaching experimental sciences. Journal High School. 2021 
In general terms, study motivation can be one of the factors, for which there is a decrease in scientific vocations by students, since according to Toma (2021), academic motivation depends on the expectations of success, beliefs of value and Cost, in other words, includes the beliefs of success and value for the study of science, the importance of highlighting and finding the usefulness of science through the curricula, however, one must also be aware of the Efforts and aspects has to be renounced that the study of this area of knowledge entails.

In Graphic 7 the responses of the teachers are revealed according to the dynamics in the class, since there will be no changes in the learning processes and the daily practices of the students, but there is a progressive modification in the teaching processes ( Baraldi, Bernik \& Diaz, 2021).

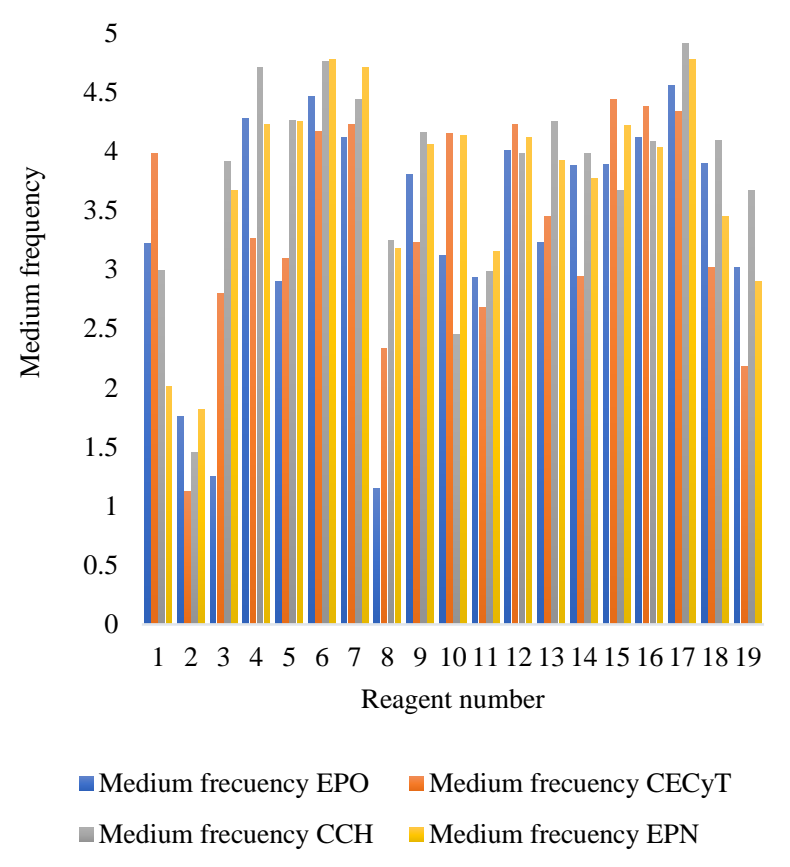

Graphic 7 Average frequency of teachers' responses for the dynamics factor

In relation to the teachers' responses, the following aspects stand out: the CECyT teachers agree with the use of textbooks as the best teaching resource, this is a problem because traditional textbooks only develop scientific knowledge, but they do not promote meaningful learning; Perhaps one of the possible reasons is the lack of knowledge and mastery of active materials, on the part of the teaching staff (Caminal \& Puigcerver, 2021, p.130).
It should be emphasized that one of the items with less average frequency corresponds to promoting hetero-evaluation, co-evaluation and self-evaluation in classes, it is unavoidable to modify this conception, since it is necessary to conceive evaluation as a means to detect any deficiency in the process in time education and take the necessary measures to improve this situation (Cañal, García \& Cruz, 2016), that is, it must permeate the entire teaching-learning process. With all of the above, it is highlighted that teachers identify the importance of implementing varied strategies and a greater number of experimental activities that are contextualized with the students' experiential environment, since it is assumed that students learn when they link what is seen in class with what happens in their daily life that allows them to understand the world that surrounds them (Molina \& González, 2021).

From the above, it follows that it is necessary to organize teaching so that learning is useful not only for the educational context, but also in the daily development of students and relativize the status of school knowledge and work more daily knowledge, with the In order for them to progressively become richer, more complex and valid to understand reality (Cañal, García \& Cruz, 2016), for this purpose, it is necessary for teachers to be trained through courses and to be concerned about their growth ( Bosch, 2014).

According to the reasoning that has been carried out, it is evident then that one of the main tasks of teachers is to understand the emotions, attitudes, beliefs and judgments of students, since in the educational field there is the problem to assume that this is a responsibility of the students, thus forgetting that the emotions they perceive are caused by the academic environment (Mujica, 2018, pp. 19-20).

In addition, the rapid evolution of knowledge makes it mandatory for post-school or post-university recycling to exist, not only because of specialized knowledge, but also to address major problems such as globalization, the economy and the economy, among others (Morin, 2011, p.155), a through the implementation of teaching strategies and learning materials in which young people participate in the construction of their own learning (Pekrun, 2014). 


\section{Conclusion}

The evidence presented above allows us to deduce the importance of considering cognitive and emotional aspects in the teaching-learning process, which have been studied in a large number of investigations, proving the benefit of contemplating these factors in the educational field, so there is no It is surprising that the main difficulties in studying and choosing careers in the areas of experimental sciences are directed towards motivation and dynamics in class, leaving aside the factor of self-determination that leads to much-needed creativity and innovation. nowadays.

Although it is true that in this work it was not found, any problem other than those referred to by the theoretical experts served to distinguish which ones have a greater presence in the classrooms, knowing the perception of the main actors in the educational process.

From the previous perspective, it was found that teachers are still linked to the use of textbooks and there is even some resistance to the change of teaching resources that today due to the knowledge and information society are within the reach of teachers and students, especially in the health contingency derived from Covid-19.

Likewise, it is mandatory to attend to the form of evaluation that the teachers implement, since it is not only essential to identify if the young person achieved learning, but also to measure how well he understood it and if it is considered that the evaluation process is not congruent With the objectives, the didactics and the performance of the learner cause frustration in the students, since they do not understand that they are being asked.

Finally, as has been stated, it is essential that teachers are trained in learning techniques and curricular knowledge, to avoid boring classes, eliminate decontextualized strategies and the lack of commitment on the part of students towards their studies. Similarly, a holistic evaluation process is required that includes qualitative and quantitative factors.

\section{Acknowledgments}

This work was carried out with the support of the UNAM-DGAPA-INFOCAB-PB100821

Initiative.

\section{References}

Agudelo, K. P., Flórez, E. P., Ravanal M., E. \& Figueroa, R. (2021). El conocimiento pedagógico del contenido (CPC) por el profesor universitario en el uso del método de resolución de problemas. Revista Boletín Redipe, 10(1), 159-172.

Aguilar, J., González, D. \& Aguilar, A. (2016). Un modelo estructural de motivación intrínseca. Acta de Investigación Psicología 6, 2552-2557.

Araque, N. (2011). Reflexiones en torno a la enseñanza de las ciencias naturales en las escuelas españolas. Nova scientia 3(5), 143-163.

Araújo, M., \& Ballesta, M. (2019). Alfabetización científica: pensamiento y prácticas de enseñanza del profesorado de física en el bachillerato de educación secundaria en Uruguay. Avances En La Enseñanza De La Física, 1(1), 9-34.

Ardura, D., \& Pérez, A. (2018). The effect of motivation on the choice of chemistry in secondary schools: adaptation and validation of the Science Motivation Questionnaire II to Spanish students. Chemistry Education Research and Practice, 19(3), 905-918.

Bandura, A. (1995). Self-efficacy in changing societies. Cambridge: University Press.

Baraldi, V., Bernik, J. \& Diaz, N. (2021). Una didáctica para la formación docente: dimensiones y principios para la enseñanza. Santa fe: Ediciones UNL.

Barberá, O. (2002). El área de «didáctica de las ciencias experimentales»: ¿apuesta de futuro o error del pasado? Revista de educación 328(2002),97-109.

Bosch, H.E. (2014). Un marco didáctico de enseñanza de ciencias, tecnología, ingeniería y matemática para la sociedad contemporánea $\left(1^{\circ} \mathrm{ed}\right)$. Ciudad Autónoma de Buenos Aires: Dunken.

Caminal, A., \& Puigcerver, M. (2021). Diseños de campus virtual: descripción de la oferta actual en la enseñanza de las Ciencias Experimentales y su influencia en el uso por parte del alumnado universitario. Didacticae: Revista De Investigación En Didácticas Específicas, (2), 119-133.

MONROY-CARREÑO, Mireya, MONROY-CARREÑO, Patricia and MONROY-CARREÑO, Roberto. The perception of the problems of teaching experimental sciences. Journal High School. 2021 
Cañal, P. García, A. \& Cruz, M. (2016). Didáctica de las ciencias experimentales en educación primaria. Madrid, España: Ediciones Paraninfo, S.A.

Chamizo, J. A. \& Pérez, J. (2017). Sobre la enseñanza de las ciencias naturales. Revista Iberoamericana de Educación, 74(1), 23-40.

Cuevas, A., Hernández, R., Leal, B. E. \& Mendoza, C. P. (2016). Enseñanza-aprendizaje de ciencia e investigación en educación básica en México. Revista Electrónica de Investigación Educativa, 18(3), 187-200.

Dávila, M.A.; Borrachero, A.B.; Mellado, V. \& Bermejo, M. L. (2015). Las emociones en alumnos de ESO en el aprendizaje de contenidos en Física y Química, según el género. Revista de psicología, 1(1), 173-180.

Domínguez, J. \& Pino, M. (2014). Motivación intrínseca y extrínseca: Análisis en adolescentes gallegos. Revista de psicología, 1(1), 349-358.

Furman, M., Luzuriaga, M., Taylor, I., Anauati, M. V., \& Podestá, M. E. (2018). Abriendo la "caja negra" del aula de ciencias: un estudio sobre la relación entre las prácticas de enseñanza sobre el cuerpo humano y las capacidades de pensamiento que se promueven en los alumnos de séptimo grado. Enseñanza de las ciencias, 36(2), 0081-103.

Galleguillos, P. \& Olmedo, E. (2017). Autoeficacia académica y rendimiento escolar: un estudio metodológico y correlacional en escolares. ReiDoCrea, 6, 156-169.

Garzón, M. A. \& Pérez, R. (2015). Lenguaje y los modelos en la enseñanza de la química. El caso de fenómeno químico. Actas ALFE Asociación Latinoamericana de Filosofía de la Educación, AC 3. http://filosofiaeducacion.org/actas/index.php/ac t/article/view/153

González, F. (Coord). (2015). Didáctica de las ciencias para la educación primaria. Madrid, España: Pirámides.

González, I., Vázquez, M. \&, Zavala, M. (2021). La desmotivación y su relación con factores académicos y psicosociales de estudiantes universitarios. Revista Digital de Investigación en Docencia Universitaria, 15(2), e1392.
Herrada, R. I. \& Baños, R. (2018). Revisión de experiencias de aprendizaje cooperativo en ciencias experimentales. Campo abierto, 36(2), 157-170.

Izar, J. M., Ynzunza, C. B. \& López, H. (2011). Factores que afectan el desempeño académico de los estudiantes de nivel superior en Rioverde, San Luis Potosí, México. CPU-e, Revista de Investigación Educativa, (12), 88-102.

Likert, S. (2010). Perceptions-about-CTSUsing-5-point. Download Scientific diagram Perceotions about CTS (Using 5 pointLikert, Scale-1 Stro. R. http://www..reseorchgate.net/.../

López, Z. (2015). La enseñanza de las ciencias naturales desde el enfoque de la apropiación social de la ciencia, la tecnología y la innovación ASCTI, en educación básica-media. Revista científica, 2(22), 75-84.

López, C. M., Ramírez, L. D. \& Espinoza, E. A. (2018). La implementación de la actividad experimental desde los fundamentos de la mediación didáctica en docentes en formación en ciencias. Góndola, Enseñanza y Aprendizaje de las Ciencias, 13(2), 251-271.

Lorca, A. A., \& Retana, D. A. (2021). El contexto en el aprendizaje de las ciencias, ¿de quién y para qué? In Libro de Memorias XII Festival Internacional de Matemáticas XXII Congreso Nacional de Ciencia, Tecnología y Sociedad (p. 30).

Lupión, T., Franco, A.J. \& Girón, J.R. (2019). Predictores de vocación en Ciencia y Tecnología en jóvenes: Estudio de casos sobre percepciones de alumnado de secundaria y la influencia de participar en experiencias educativas innovadoras. Revista Eureka sobre Enseñanza y Divulgación de las Ciencias, 16(3), 3102.

Macedo, B. (2016). Educación científica. Montevideo, Uruguay: UNESCO.

Martínez, N. Y. \& Riveros, S. Y. (2019). La enseñanza de caída libre bajo la metodología de aprendizaje activo. Tecné Episteme y Didaxis: TED, (45), 35-56.

Mendoza, C. P., Leal, B.E. \& Hernández, R. (2014). Administración de la enseñanza de ciencias naturales en educación básica. Criterio Libre, 12 (21), 117-136. 
Molina, N. \& González, P. (2021). Ciencias naturales y aprendizaje socioemocional: una experiencia desde la enseñanza de las ciencias basada en la indagación. Revista Saberes Educativos, (6), 25-58.

Mordeglia, C. \& Mengascini, A. (2014). Caracterización de prácticas experimentales en la escuela a partir del discurso de docentes de primaria y secundaria. Enseñanza de las ciencia 32(1), 1-19.

Morin, E., (2011). La vía. Para el futuro de la humanidad. Barcelona, España: Paidós.

Mujica, F.N. (2018). Educar y suscitar emociones en la educación: análisis crítico de su contribución al desarrollo moral. ENSAYOS, Revista de la Facultad de Educación de Albacete, 33(2), 15-27.

Mumbardó, C., Vicente, E., Giné, C., Guardia, J., Raley, S. \& Verdugo, M.A. (2017). Promoviendo la autodeterminación en el aula: el Modelo de Enseñanza y Aprendizaje de la Autodeterminación. Siglo Cero, 48(2), 41-59.

Neira, J.C.R. (2021). La experimentación en ciencias naturales como estrategia de alfabetización científica. Revista Académica del Maule, 60, 102-116.

Ortiz, F. L. \& Álava, C. (2021). Formación científica: un desafío para la educación mediada. UNAD.

https://hemeroteca.unad.edu.co/index.php/book/ article/view/4665/4436

Pekrun, R. (2014). Emotions and learning. Oficina Internacional de Educación de la UNESCO [11994], Academia Internacional de Educación, 1-32. https://unesdoc.unesco.org/ark:/48223/pf00002 27679

Pelcastre, L.; Gómez, A. R. \& Zavala, G. (2015). Actitudes hacia la ciencia de estudiantes de educación preuniversitaria del centro de México. Revista Eureka sobre Enseñanza y Divulgación de las Ciencias, 12(3), 475-490.

Polino, C. (2012). Las ciencias en el aula y el interés por las carreras científico-tecnológicas: Un análisis de las expectativas de los alumnos de nivel secundario en Iberoamérica. Revista Iberoamericana de Educación 58(2012), 167191.
Rodríguez, C.M. \& González, M.A. (2018). Una mirada al logro educativo mexicano en lenguaje, matemáticas y ciencias. Entreciencias: Diálogos en la Sociedad del Conocimiento, 6(17), 51-64.

SEP, (2017). Campo Disciplinar de Ciencias Experimentales Bachillerato GeneralAdecuación de contenidos de las asignaturas del componente de formación propedéutica básica. https://bit.ly/30ZYxNZ

Toma, R.B. (2021). Evidencias de validez de una medida de la motivación por las ciencias de la naturaleza. Educación XX1, 24(2), 351-374.

Torres, H. M. (2020). Secuencia Didáctica de un Módulo Educativo en Ciencias Experimentales para Jóvenes de bachillerato. Hernández, G.M. (Ed). Prácticas Innovadoras en el Contexto Universitario, (73-90). $\mathrm{T} \& \mathrm{R}$ Desarrollo Empresarial S.A. de C.V.

Torres, M. I. (2010). La enseñanza tradicional de las ciencias versus las nuevas tendencias educativas. Revista electrónica Educare, 14(1),131-142.

Vargas, J. A. (2013). Implicaciones de la teoría motivacional de la Autodeterminación en el ámbito laboral. Nova scientia, 5(9), 154-175. 